\title{
PERAN AGAMA DALAM MENENTUKAN KEPUTUSAN PERNIKAHAN PADA GENERASI MILLENIAL
}

\author{
Akbar Nicholas Saputra ${ }^{1}$, Tita Agustina² \\ ${ }^{1}$ Program Studi Bimbingan Penyuluhan Islam \\ Fakultas Dakwah dan Ilmu Komunikasi UIN Sayrif Hidayatullah \\ Email: akbar.saputra21@mhs.uinjkt.ac.id \\ 2Program Studi Bimbingan Penyuluhan Islam \\ Fakultas Dakwah dan Ilmu Komunikasi UIN Sayrif Hidayatullah \\ Email: tita.agustina21@mhs.uinjkt.ac.id
}

\begin{abstract}
This study aims to examine the role of religion in determining marriage decisions among millennials. The shift in values, roles, and interests among the millennial generation is a problem for him in determining marriage decisions. In this study, the authors took data by filling out a questionnaire with open answers and closed answers using a google form. The object of this research is the millennial generation (born 1997-2003), with a total of 87 participants. The research method used in this study is a qualitative research method with the approach used in this study being an approach to content analysis. Based on the research that the author conducted, the millennial generation is divided into two groups, namely the group that believes marriage accelerates (26.4\%) and the group that believes it does not accelerate marriage (73.6\%). The results of filling out the questionnaire as many as $96.6 \%$ of the millennial generation think that the role of religion in determining marriage decisions is important. In determining the decision to marry, millennials also pay attention to several other factors that support the decision to undergo marriage, such as economic factors, mental readiness, and age factors. Almost all decisions (95.4\%) of millennials also think that marriage can increase piety to God Almighty. Based on the results of the research conducted, the authors can conclude that religion has a very important role in making marriage decisions among the millennial generation. Based on religion, the marriage carried out will get the blessing of Allah SWT and the journey in domestic life will get blessings. The role of religion can also lead humans to goodness and be kept away from all damage and can increase faith and piety to Allah swt.
\end{abstract}

Keywords: Religion, Marriage, Decisions, Millennials

\begin{abstract}
Abstrak
Penelitian ini bertujuan untuk mengkaji peran agama dalam menentukan keputusan pernikahan di kalangan milenial. Pergeseran nilai, peran, dan kepentingan di kalangan generasi milenial menjadi kendala baginya dalam menentukan keputusan pernikahan. Dalam penelitian ini, penulis mengambil
\end{abstract}


data dengan cara mengisi kuesioner dengan jawaban terbuka dan jawaban tertutup menggunakan google form. Objek penelitian ini adalah generasi milenial (kelahiran 1997-2003), dengan jumlah peserta 87 orang. Metode penelitian yang digunakan dalam penelitian ini adalah metode penelitian kualitatif dengan pendekatan yang digunakan dalam penelitian ini adalah pendekatan analisis isi. Berdasarkan penelitian yang penulis lakukan, generasi milenial terbagi menjadi dua kelompok, yaitu kelompok yang meyakini mempercepat pernikahan $(26,4 \%)$ dan kelompok yang meyakini tidak mempercepat pernikahan $(73,6 \%)$. Hasil pengisian kuesioner sebanyak $96,6 \%$ generasi milenial berpendapat bahwa peran agama dalam menentukan keputusan pernikahan itu penting. Dalam menentukan keputusan pernikahan, kaum milenial juga memperhatikan beberapa faktor lain yang mendukung keputusan menjalani pernikahan, seperti faktor ekonomi, kesiapan mental, dan faktor usia. Hampir semua keputusan $(95,4 \%)$ kaum milenial juga berpendapat bahwa pernikahan dapat meningkatkan ketakwaan kepada Tuhan Yang Maha Esa. Berdasarkan hasil penelitian yang dilakukan, penulis dapat disimpulkan bahwa agama memiliki peran yang sangat penting dalam pengambilan keputusan pernikahan di kalangan generasi milenial. Berdasarkan agama, pernikahan yang dilakukan akan mendapatkan ridho Allah SWT dan perjalanan dalam kehidupan rumah tangga akan mendapatkan berkah. Peran agama juga dapat mengantarkan manusia kepada kebaikan dan dijauhkan dari segala kerusakan serta dapat meningkatkan keimanan dan ketakwaan kepada Allah swt.

Kata Kunci: Agama, Pernikahan, Peputusan, Milenial

\section{A. Pendahuluan}

Berdasarkan penelitian sebelumnya yang dilakukan oleh Wibisana (2016) pernikahan adalah suatu bentuk keseriusan dalam sebuah hubungan. Selain merupakan bentuk cinta, pernikahan dalam Islam merupakan salah satu bentuk ibadah kepada Allah. Bahkan, disebutkan bahwa pernikahan adalah menggenapkan setengah agama. ${ }^{1}$ Sedangkan menurut penelitian yang dilakukan oleh Roziki (2018) mengatakan bahwa mentaati syariat pernikahan merupakan bagian dari ibadah kepada Allah yaitu dengan menaati aturan-Nya dengan segenap puncak cinta dan penghinaan diri, maka membahas syariat pernikahan dalam Islam harus dilakukan dalam syariat

1 Wahyu Wibisana, 'PERNIKAHAN DALAM ISLAM', Jurnal Pendidikan Agama Islam, 14 (2016), 9. 
pernikahan yang dibahas bukan dengan cara pandang duniawi seperti membahas pernikahan semata-mata untuk menargetkan hidup bahagia, tetapi dipelajari dalam rangka melaksanakan tugas ibadah Allah yang telah menciptakan dunia ini agar kita mampu taat terhadap segala perintahNya dan menjauhi segala larangannya. ${ }^{2}$ Penelitian yang dilakukan oleh Zulfikar (2020) mengatakan bahwa seseorang yang menunda menikah ialah seseorang yang tergolong dalam kesengsaraan karena tidak menikmati kebahagiaan secara biologis maupun spiritual dan enggan untuk mensyukuri karunia yang telah Allah berikan. ${ }^{3}$

Namun berdasarkan penelitian yang dilakukan oleh Sudrajat (2014) mengatakan bahwa menunda menikah dengan tujuan untuk mencapai kemapanan ekonomi dan kesiapan mental tidak bertentangan dengan hukum Islam sebab kewajiban seorang laki-laki ialah menafkahi dan menjadi imam bagi keluarga. ${ }^{4}$ Maka perbedaan penelitian ini dengan penelitian sebelumnya terletak pada pentingnya peran agama bagi generasi milenial dalam menentukan keputusan pernikahan serta menjabarkan beberapa faktor yang menjadi salah satu hal penting dalam pengambilan keputusan pernikahannya.

Masalah yang terjadi di masyarakat mengenai penentuan keputusan pernikahan di kalangan milenial disebabkan karena adanya pergeseran nilai, peran, dan kepentingan yang jauh berbeda dari generasi sebelumnya. Banyaknya generasi milenial yang berfikiran bahwa dengan menyelenggarakan pernikahan dapat menghambat karir, pendidikan, bahkan menghambat kebebasan dan kebahagian untuk dirinya sendiri. Seperti yang dikatakan oleh Andhika (2020) bahwa kaum milenial semakin strategis

\footnotetext{
2 Mokhamad Rohma Roziki, 'Konsepsi Pernikahan Dalam Islam Dan Perannya Dalam Menjaga Adab Interaksi Pria-Wanita', Waskita, 2 (2018), 71-82.

3 Zulfikar, 'Menunda Pernikahan, Haramkah?', 2019 <https://bincangsyariah.com/kalam/menunda-pernikahan-haramkah/>.

4 Ajat Sudrajat, 'MENUNDA PERNIKAHAN DALAM ISLAM: Kontruksi Sosial Pelaku Telat Nikah Pada Masyarakat Cisayong Kabupaten Tasikmalaya', Kodifikasia, 8.1 (2014) <https://doi.org/10.21154/kodifikasia.v8i1.110>.
} 
merencanakan karir dan masa depan finansial, termasuk pandangan politik, pendidikan dan agama. Bagi kaum Millenial, hal-hal seperti berkarir, meneruskan pendidikan, dan membahagiakan dirinya sendiri lebih masuk akal untuk diperjuangkan daripada langsung menikah dan membesarkan anak-anak. Karena kekritisannya ini, mereka akhirnya mampu membangun hubungan yang kuat dan sukses, berdasarkan saling pengertian, kasih sayang, solidaritas dan penyamaan nilai. ${ }^{5}$

Dalam QS. Al-Isra ayat 37 dikatakan bahwa sebagai manusia seharusnya mampu menghindari zinah dan cara yang tepat untuk menghindari zinah tersebut ialah dengan melangsungkan pernikahan. ${ }^{6}$ Dalam hadits yang diriwayatkan oleh Mutaffaqun Alaih dikatakan bahwa pemuda yang sudah mampu menikah, maka menikahlah dan apabila belum mampu berpuasalah.

Berdasarkan dua pandangan mengenai pernikahan yang terjadi pada generasi milenial, maka artikel ini dibuat untuk mengetahui beberapa hal mengenai pandangan yang ada tersebut, diantaranya ialah untuk (1) mengetahui seberapa penting faktor agama dalam menentukan pernikahan bagi generasi milenial dan (2) mengetahui faktor serta asalan mengenai pendapat generasi milenial yang beranggapan untuk menyegerakan pernikahan dan menunda pernikahan.

Adapun tujuan dari penelitian ini adalah untuk memberikan informasi bagi kami sebagai penulis dan juga pembaca mengenai pentingnya peran agama dalam menentukan keputusan pernikahan bagi generasi milenial. Berdasarkan dari pemikiran generasi milenial secara umum mengenai pernikahan maka penulis memutuskan bahwa artikel kami yang berjudul Peran Agama Dalam Menentukan Keputusan Pernikahan Pada Generasi Millenial menjadi fokus pada penelitian ini untuk menjelaskan seberapa pentingnya agama bagi generasi milenial dan juga menjelaskan beberapa

${ }^{5}$ Andhika, 'Pernikahan Di Era Milenial Dipandang Lebih Rasional' (ajaib.co.id, 2020) <https://ajaib.co.id/pernikahan-di-era-milenial-dipandang-lebih-rasional/>.

${ }^{6}$ Kementrian Agama, QS. Al-Isra Ayat 32. 
faktor pendukung lainnya mengenai pengambilan keputusan generasi milenial dalam menentukan keputusan pernikahannya.

\section{B. Metode Penelitian}

Metode penelitian yang digunakan dalam penelitian ini adalah metode penelitian kualitatif. Pendekatan yang dipakai dalam penelitian ini ialah pendekatan pada analisis isi. Tujuan dari analisis isi adalah untuk mengatur dan menarik makna dari data yang sudah terkumpul dan mengambil kesimpulan realistis berdasarkan makna yang terkumpul tersebut. Melalui analisis isi, penulis dapat mengolah segala jenis data tertulis, seperti halnya adalah pertanyaan open-ended dalam sebuah kuesioner, sehingga penulis memutuskan untuk menggunakan kuesioner berisi pertanyaan terbuka atau open-ended question dan juga menggunakan kuisioner yang berisi pertanyaan tertutup sebagai teknik penggalian data.

Teknik penentuan partisipan yang digunakan dalam penelitian ini adalah purposive sampling. Tidak ada kriteria tertentu dalam penentuan jumlah responden yang hendak diteliti. Partisipan dalam penelitian ini adalah 87 generasi milenial kelahiran 1996-2004 yang mengisi kuesioner dalam bentuk jawaban yang tertutup dan 35 generasi milenial kelahiran 1991-2004 yang mengisi kuesioner dalam jawaban terbuka. Dari partisipan yang secara keseluruhan berjumlah 122 partisipan terbagi menjadi dua kelompok sesuai dengan keputusan mereka, yaitu keputusan untuk menyegerakan pernikahan sebanyak 37 (30,3\%) partisipan dan keputusan untuk tidak menyegerakan pernikahan sebanyak 85 (69,7\%) partisipan yang tinggal di Indonesia, dan telah membaca informed consent dengan seksama serta bersedia untuk terlibat sebagai partisipan dengan mengisi kuesioner secara lengkap. Partisipan dalam penelitian ini berusia 17-30 tahun dengan partisipan yang berusia 17 tahun sebanyak 7 orang, berusia 18 tahun sebanyak 42 orang, berusia 19 tahun sebanyak 28 orang, berusia 20 tahun sebanyak 11 orang, berusia 21 tahun sebanyak 11 orang, berusia 22 tahun sebanyak 7 orang, berusia 23 tahun sebanyak 5 orang, berusia 24 tahun sebanyak 3 orang, 
berusia 25 tahun sebanyak 1 orang, berusia 26 tahun sebanyak 2 orang, berusia 28 tahun sebanyak 3 orang, dan yang berusia 30 tahun sebanyak 2 orang.

Teknik pengorganisasian dan analisis data yang dilakukan dalam penelitian ini adalah dengan mengidentifikasi kuesioner dari jawaban tertutup serta mengidentifikasi unit makna, memasukkan konten relevan dan membuang data yang tidak relevan, identifikasi grup yang serupa, kemudian tarik kesimpulan yang realistis. Penulis menganggap penggunaan metode ini cocok untuk mendeskripsikan peran agama dalam menentukan keputusan pernikahan di kalangan milenial yang mana keputusan tersebut terbagi menjadi dua kelompok keputusan, yaitu keputusan untuk menyegerakan pernikahan dan keputusan untuk tidak menyegerakan pernikahan.

\section{Pembahasan}

Berdasarkan kuisioner yang disebarkan secara acak oleh penulis, berikut hasil dari jawaban responden terhadap pertanyaan-pertanyaan yang dijawab olehnya dalam bentuk table dan penjelasan yang ada dibawahnya.

\begin{tabular}{|c|l|c|c|}
\hline No. & \multicolumn{1}{|c|}{ Question } & Yes & No \\
\hline 1. & $\begin{array}{l}\text { Apakah Anda termasuk } \\
\text { generasi Millenial yang } \\
\text { menyegerakan pernikahan? }\end{array}$ & $\frac{64}{87} \times 100 \%=$ & $\frac{23}{87} \times 100 \%=$ \\
\hline 2. & $\begin{array}{l}\text { Apakah agama menjadi peran } \\
\text { penting bagi Anda sebagai } \\
\text { generasi Millenial dalam } \\
\text { menentukan keputusan } \\
\text { pernikahan? An }\end{array}$ & $\frac{84}{87} \times 100 \%=$ & $\frac{3}{87} \times 100 \%=$ \\
\hline 3. & $\begin{array}{l}\text { Apakah Anda setuju dengan } \\
\text { pernikahan dapat menuntun } \\
\text { kepada hal-hal baik? }\end{array}$ & $\frac{81}{87} \times 100 \%=$ & $\frac{6}{87} \times 100 \%=$ \\
\hline 4. & $\begin{array}{l}\text { Apakah Anda setuju dengan } \\
\text { pernikahan dapat } \\
\text { meningkatkan ketakwaan Anda } \\
\text { terhadap Tuhan YME? }\end{array}$ & $\frac{83}{87} \times 100 \%=$ \\
\hline
\end{tabular}




\begin{tabular}{|c|c|c|c|}
\hline 5. & $\begin{array}{l}\text { Apakah Anda setuju dengan } \\
\text { pernikahan dapat menjaga } \\
\text { Anda dari kejahatan dan } \\
\text { kerusakan? }\end{array}$ & $\begin{array}{c}\frac{69}{87} \times 100 \%= \\
79,3 \%\end{array}$ & $\begin{array}{c}\frac{18}{87} \times 100 \%= \\
20,7 \%\end{array}$ \\
\hline 6. & $\begin{array}{l}\text { Apakah Anda setuju dengan } \\
\text { pernikahan dapat menjalin } \\
\text { hubungan tali silaturahmi yang } \\
\text { baik? }\end{array}$ & $\begin{array}{c}\frac{83}{87} \times 100 \%= \\
95,4 \%\end{array}$ & $\begin{array}{c}\frac{4}{87} \times 100 \%= \\
4,6 \%\end{array}$ \\
\hline 7. & $\begin{array}{lrr}\text { Apakah faktor usia } & \text { menjadi } \\
\text { alasan utama Anda } & \text { sebagai } \\
\text { generasi Millenial dalam } \\
\text { menentukan } & \text { keputusan } \\
\text { pernikahan? } & \\
\end{array}$ & $\begin{array}{c}\frac{45}{87} \times 100 \%= \\
51,7 \%\end{array}$ & $\begin{array}{c}\frac{42}{87} \times 100 \%= \\
48,3 \%\end{array}$ \\
\hline 8. & $\begin{array}{l}\text { Apakah faktor ekonomi } \\
\text { menjadi salah satu alasan Anda } \\
\text { sebagai generasi Millenial } \\
\text { dalam menentukan keputusan } \\
\text { pernikahan? }\end{array}$ & $\frac{60}{87} \times 100 \%=69 \%$ & $\frac{27}{87} \times 100 \%=31 \%$ \\
\hline 9. & $\begin{array}{l}\text { Apakah faktor pendidikan } \\
\text { pasangan menjadi salah satu } \\
\text { alasan Anda sebagai generasi } \\
\text { Millenial dalam menentukan } \\
\text { keputusan pernikahan? }\end{array}$ & $\frac{47}{87} \times 100 \%=54 \%$ & $\frac{40}{87} \times 100 \%=46 \%$ \\
\hline 10. & $\begin{array}{l}\text { Apakah faktor kesiapan mental } \\
\text { menjadi alasan untuk Anda } \\
\text { sebagai generasi Millenial } \\
\text { dalam menentukan keputusan } \\
\text { pernikahan? }\end{array}$ & $\begin{array}{c}\frac{83}{87} \times 100 \%= \\
95,4 \%\end{array}$ & $\begin{array}{c}\frac{4}{87} \times 100 \%= \\
4,6 \%\end{array}$ \\
\hline \multicolumn{4}{|c|}{$\begin{array}{l}\text { Keterangan: } \\
\frac{a}{b} \times 100 \%=n \\
a=\text { Banyaknya jawaban yang dipilih responden } \\
b=\text { Banyaknya responden secara keseluruhan } \\
n=\text { Hasil yang didapat dalam bentuk persen (\%) }\end{array}$} \\
\hline
\end{tabular}

Tabel 1 Hasil Penelitian

Berdasarkan penelitian yang dilakukan melalui pengisian kuesioner dengan jawaban tertutup hasil yang menunjukan jawaban dari pertanyaan 
apakah agama menjadi peran penting bagi Anda sebagai generasi milenial dalam menentukan keputusan pernikahan berjumlah $(96,6 \%)$ atau sebanyak 84 partisipan mengatakan setuju dengan pernyataan dari pertanyaan tersebut dan berdasarkan hasil penelitian dengan jawaban terbuka menunjukan bahwa (97\%) partisipan menganggap bahwa agama menjadi peran yang sangat penting dalam menentukan keputusan pernikahan. Berdasarkan dari keterangan partisipan yang menjawab kuesioner dalam jawaban terbuka mengatakan alasan pentingnya peran agama dalam menentukan keputusan pernikahan adalah sebagai point utama dengan bekal agama pernikahan akan selalu terarah dalam aturan-aturan agama sehingga suami dan istri tidak ada yang melenceng melanggar aturan allah yang membuat salah satu dari kedua belah pihak kecewa ${ }^{7}$ ada juga partisipan yang menjawab kuesioner dalam jawaban terbuka mengatakan alasan pentingnya agama dalam menentukan keputusan pernikahan adalah karena agama sebagai patokan kita untuk hidup baik untuk kehidupan di masa lalu, kini dan masa depan. Agama menjadi landasan tentang apapun dalam kehidupan yang menyangkut dengan memutuskan suatu pilihan. Agama menjadi peran penting di pernikahan karena mengajarkan bagaimana tata cara, adab, dan etika kita dalam membina rumah tangga dan juga dalam memecahkan masalah, memunculkan solusi, pembentukan karakter dan akhlak untuk anak-anak kita kelak, dalam bermasyarakat dan masih banyak $\operatorname{lagi.}{ }^{8}$

Pentingnya peran agama dalam menentukan keputusan pernikahan di kalangan generasi milenial ialah peran agama dapat menuntun pada hal-hal kebaikan di mana pernyataan ini disetujui oleh $(93,1 \%)$ atau sama dengan 81 partisipan yang mengisi kuesioner ini bahwa dengan pernikahan dapat menuntun pada hal-hal kebaikan yang akan membimbing pada pencapaian ridho Allah Swt. Pentingnya peran agama dalam pernikahan juga dapat

\footnotetext{
7 Partisipan, 'Jawaban Kuisioner Terbuka'.

8 Partisipan.
} 
meningkatkan ketakwaan kepada Tuhan Yang Maha Esa yang mana pernyataan ini disetujui oleh hampir seluruh partisipan yaitu sebanyak $(95,4 \%)$ atau sama dengan 83 partisipan yang mengisi kuesioner ini dengan sepakat bahwa pernikahan akan menghadirkan suatu ketakwaan kepada Allah Swt. karena telah berusaha untuk menghindari zinah dan maksiat. Dengan penerapan peran agama yang kuat pernikahan juga dapat menjaga dari kejahatan dan kerusakan di mana pada pernyataan tersebut sebanyak $(79,3 \%)$ atau sama dengan 69 partisipan menyetujui hal itu akan tetapi $(20,7 \%)$ atau sama dengan 18 partisipan tidak menyetujui hal tersebut, di mana ketidak setujuan tersebut karena alasan adanya kasus kekerasan dalam rumah tangga yang terjadi dalam pernikahan sehingga dengan melaksanakan pernikahan tidak menjamin seseorang terhindar dari kejahatan dan keburukan. Penelitian terakhir mengenai pentingnya peran agama dalam menentukan keputusan pernikahan di kalangan milenial ialah dengan pernikahan akan menjalin tali silaturahmi yang baik dengan jawaban partisipan hampir keseluruhan menyetujui pernyataan tersebut setidaknya sebanyak $(95,4 \%)$ atau sama dengan 83 partisipan setuju dengan hal tersebut sebab dengan pernikahan akan menjalin tali silaturahmi dengan keluarga pasangan yang jika berlandaskan agama yang kuat maka jalinan silaturahmi tersebut akan berjalan baik.

Berdasarkan dari jawaban partisipan dapat dikatakan bahwa agama memiliki peran penting dalam segala aspek kehidupan termasuk dalam menentukan keputusan pernikahan di kalangan generasi milenial. Berdasarkan kutipan yang diambil dari Melyloelhabox (2012) Pernikahan adalah bagian dari takdir Tuhan Yang Maha Esa dengan menyakini bahwa manusia adalah makhluk yang lemah sehingga sewaktu-waktu manusia akan menghadirkan dirinya pada Tuhan Yang Maha Esa. Dengan adanya keyakinan kepada Tuhan Yang Maha Esa melalui keyakinan agama yang dianutnya maka agama akan memberikan tuntunan dan bimbingan kepada pemeluknya dengan mengarahkan kepada hal-hal yang baik dan menjauhkan diri dari 
sifat tercela. ${ }^{9}$ Dengan demikian jika agama dikaitkan dengan perkawinan, maka agama yang dianut oleh masing-masing anggota pasangan akan memberikan tuntunan dan bimbingan bagaimana bertindak secara baik. Dengan agama atau kepercayaan yang kuat, keadaan ini akan dapat digunakan sebagai benteng yang tangguh untuh menanggulangi perbuatanperbuatan yang tidak terpuji.

Berdasarkan yang dikatakan oleh Wibisana (2016) bahwa untuk mencapai suatu kemaslahatan atau kebaikan dalam pernikahan setiap pasangan yang bersangkutan harus memperhatikan serta menaati aturanaturan yang tertera dalam agama yang dianutnya agar pernikahan yang dijalani menuntun kepada jalan yang diridhoi oleh Tuhan Yang Maha Esa dan dapat menimbulkan perbuatan-perbuatan yang mencerminkan akhlak terpuji. ${ }^{10}$

Berdasarkan pada penelitian yang penulis lakukan dari hasil kuesioner yang dibagikan kepada partisipan terdapat dua temuan pendapat mengenai keputusan pernikahan di kalangan milenial. Penulis mendapatkan jawaban sebanyak $(69,6 \%)$ atau sama dengan 85 dari partisipan yang menjawab bahwa mereka beranggapan untuk tidak menyegerakan pernikahan dan penulis mendapatkan jawaban sebanyak $(30,4 \%)$ atau sama dengan 37 dari partisipan yang menjawab bahwa mereka beranggapan untuk menyegerakan pernikahan. Adapun alasan dari generasi milenial yang beranggapan untuk tidak menyegerakan pernikahan berdasarkan pada jawaban partisipan dalam mengisi kuesioner dengan jawaban terbuka diantaranya ialah beranggapan bahwa pernikahan bukan tentang cepat, tapi tepat. Di samping itu juga, pernikahan adalah hal yang kompleks. Karena kompleks, maka banyak hal yang harus dipersiapkan. Mulai dari kesiapan

\footnotetext{
${ }^{9}$ Unknow, 'Peranan Agama Dalam Pendekatan Kaunseling' (melyloelhabox.blogspot, 2012) <http://melyloelhabox.blogspot.com/2012/12/peranan-agama-dalamperkawinan.html>.

10 Wibisana.
} 
mental, fisik, dan juga materi. ${ }^{11}$ Terdapat pula partisipan yang beranggapan untuk tidak menyegerakan pernikahan karena kesiapan dalam pernikahan itu penting, jadi tidak bisa disegerakan jika memang belum benar-benar siap dari banyak aspek. ${ }^{12}$ Selain itu beberapa alasan dari partisipan untuk tidak menyegerakan pernikahan karena memiliki alasan untuk membahagiakan orang tua terlebih dahulu, berkarir, dan juga melanjutkan pendidikan ke jenjang yang lebih tinggi. Selain itu partisipan yang beranggapan untuk menyegerakan pernikahan memiliki alasan yang bertolak belakang dari pada pemikiran para partisipan yang beranggapan untuk tidak menyegerakan pernikahan, seperti halnya alasan dari beberapa partisipan yang beranggapan untuk menyegerakan pernikahan diantaranya karena pernikahan itu menghindarkan kita dari dosa dan mendekatkan diri kita untuk lebih dekat kepada Allah ${ }^{13}$ dan alasan lain dari partisipan yang beranggapan untuk menyegerakan pernikahan ialah karena saat ini sudah berada di akhir zaman dan kepribadian yang tidak terlalu bisa bersosialisasi sehingga tidak ada keinginan untuk bermain kesana-sini dan sebagainya. Seperti milenial pada umumnya dengan pernikahan berharap mencari pahala dan kebaikan dari pernikahan tersebut dan juga ingin menyempurnakan separuh agama untuk hal tersebut. ${ }^{14}$

Setiap manusia pastinya mempunyai cara pandang sendiri- sendiri mengenai pernikahan. Tetapi yang pasti pernikahan merupakan ikatan yang sakral, dan sangat berarti yang dilakukan dengan kesiapan optimal serta mesti dilakukan dengan rencana yang terencana. Berdasarkan pendapat yang dikemukakan oleh Fimale (2018) Pernikahan merupakan persoalan yang berarti untuk disegerakan demi ibadah. Melainkan bukan berarti pernikahan merupakan persoalan yang wajib dilakukan dengan terburu- buru hanya sebatas menyegerakan kata legal. Sebelum menguatkan hati guna menikah,

\footnotetext{
11 Partisipan.

12 Partisipan.

13 Partisipan.

${ }^{14}$ Partisipan.
} 
yakinkan kalau kalian memahami dengan baik keluarga calon pendamping. Peruntukan calon pendamping pula memahami baik keluarga kalian. Apa yang nampak dari suatu keluarga saat sebelum pernikahan serta sehabis pernikahan tidak sedikit akan sangat berbeda jauh. Tidak hanya menyatukan dua keluarga yang berbeda kalian dan pendamping hendaknya pula menyatukan sahabat kalian dalam kesatuan yang penuh penerimaan. Jalinan pernikahan hendak membawa kita ke dalam kehidupan yang lebih senang serta hampir sempurna. Tetapi bukan berarti tidak akan terdapat permasalahan dalam ikatan pernikahan. Masalah- masalah yang kalian alami saat sebelum menikah dengan pendamping dapat saja tidak seberapa bila dibanding dengan permasalahan yang timbul sehabis kamu menikah. Bila kalian berpikir sehabis menikah tidak akan terdapat lagi cobaan dan seluruh permasalahan dalam hidup akan berakhir, kalian salah. Ujian di dalam jalinan perkawinan yang legal, jalinan yang dibentuk sekedar buat beribadah, akan terasa lebih berat serta mewajibkan kalian lebih tabah. ${ }^{15}$ Selain itu dalam penelitiannya Bayali (2013) mengatakan bahwa menunda pernikahan demi mengejar karir belum tentu hal itu sesuatu yang baik menurut Allah swt dan untuk kita akan tetapi sebaliknya bisa jadi karir yang diharapkan tidak tercapai karena niat dan cara yang dipilih dalam mengejar karir tersebut bertentangan dengan keinginan Allah swt, yaitu menunda pernikahan. ${ }^{16}$

Faktor yang menjadi alasan generasi milenial untuk menyegerakan pernikahan dan juga tidak menyegerakan pernikahan didasari oleh faktor dalam diri dan juga faktor lingkungan masyarakat. Berdasarkan penelitian yang penulis lakukan dalam penyebaran kuesioner kepada partisipan terdapat beberapa faktor yang menjadi alasan dalam penentuan keputusan pernikahan. (1) Faktor Usia menjadi pengaruh yang cukup penting dalam menentukan keputusan pernikahan di kalangan milenial, setidaknya terdapat

\footnotetext{
15 Fimela, 'Menikah Memang Ibadah' (Fimela.com, 2018) <https://www.fimela.com/lifestyle/read/3778550/menikah-memang-ibadah-tapi-bukanhanya-sebatas-menyegerakan-kata-sah>.

16 Cip Bayali, 'Menunda Pernikahan Bagi Wanita Karir Menurut Hukum Islam', Hukum Islam, XIII.1 (2013), 84-96.
} 
jawaban partisipan sebanyak (51,7\%) atau sebanyak 45 partisipan setuju bahwa usia menjadi salah satu faktor penting dan juga faktor utama dalam menentukan keputusan pernikahan tetapi sebanyak $(48,7 \%)$ atau sama dengan 42 partisipan tidak setuju bahwa usia menjadi faktor utama dalam menentukan pernikahan sebab pernikahan dilaksanakan berdasarkan kesiapan diri dalam beberapa faktor tertentu bukan karena usianya. Selain faktor usia, (2) Faktor ekonomi juga menjadi bagian penting dalam menentukan keputusan pernikahan dari kuesioner yang disebarkan terdapat (69\%) atau sama dengan 60 partisipan menyetujui bahwa faktor ekonomi adalah salah satu faktor penting bagi generasi milenial dalam menentukan keputusan pernikahan sehingga para generasi milenial lebih memfokuskan atau mengutamakan dirinya untuk mencapai karir terbaiknya daripada menyegerakan pernikahan terlebih dahulu dan sebanyak (31\%) atau sama dengan 27 partisipan tidak setuju jika faktor ekonomi menjadi faktor utama dalam menentukan keputusan pernikahan generasi milenial karena para generasi milenial yang beranggapan ini meyakini bahwa dengan menyegerakan pernikahan maka akan dibukakan pintu rezeki oleh Tuhan Yang Maha Esa sehingga mereka beranggapan dengan menikah akan mensejahterakan dirinya dan pasangannya dalam kehidupan ekonomi. (3) Faktor pendidikan pasangan juga menjadi faktor penting bagi sebagian generasi milenial seperti halnya hasil penelitian menyatakan bahwa sebanyak (54\%) atau sama dengan 47 partisipan setuju dengan pernyataan tersebut, generasi milenial ini beranggapan bahwa pendidikan yang tinggi akan lebih menjamin kebahagiaan dalam menjalani hubungan pernikahan sehingga generasi milenial ini lebih mengutamakan pendidikannya agar mendapatkan pasangan yang sempurna daripada menyegerakan pernikahan, akan tetapi sebanyak (46\%) atau sama dengan 40 partisipan tidak menyetujui pernyataan tersebut menurut generasi milenial yang tidak menyetujui pernyataan tersebut beranggapan bahwa pendidikan pasangannya bukanlah faktor penting dalam penentuan keputusan 
pernikahan karena generasi ini menganggap bahwa dengan menyegerakan pernikahan tidak akan menghalangi seseorang untuk tetap berpendidikan tinggi dan dapat menghindari dari perkara zinah yang tidak disukai oleh Allah swt. (4) Faktor terakhir yang mungkin menjadi alasan generasi milenial dalam menentukan keputusan pernikahan ialah faktor kesiapan mental hampir dari semua responden setuju bahwa faktor ini sangat berpengaruh dalam menentukan keputusan pernikahan dalam penelitian terdapat $(95,4 \%)$ atau sama dengan 83 partisipan setuju dengan pernyataan tersebut hanya saja ada juga $(4,6 \%)$ atau sama dengan 4 partisipan tidak setuju dengan pernyataan tersebut. Faktor kesiapan mental memanglah hal penting dalam menentukan keputusan pernikahan di kalangan generasi milenial karena tanpa adanya kesiapan mental maka pernikahan yang dijalani mungkin tidak akan berjalan sesuai dengan apa yang diharapkan sebab pasangan belum memiliki kesiapan dalam berumah tangga.

Dari riset yang telah dilakukan oleh Hotnatalia (2020) ada sebagian aspek yang dianalisis yang menjadi beberapa faktor dalam menentukan keputusan pernikahan di kalangan generasi milenial, yaitu aspek ekonomi, aspek kemauan sendiri, dan aspek media massa. ${ }^{17}$ Selain dari riset tersebut terdapat riset yang dilakukan oleh Aini (2020) mengatakan bahwa yang menjadi faktor terjadinya sebuah keputusan untuk melangsungkan pernikahan ialah faktor pendidikan yang ditempuh, faktor keluarga yang berada pada kondisi ekonomi rendah, faktor ekonomi, faktor social, dan faktor lingkungan. ${ }^{18}$

Nashrullah (2020) mengatakan bahwa Islam tidak mengingkari adanya cinta seorang manusia kepada lawan jenisnya. Ia adalah fitrah dan kebutuhan mendasar yang harus dipenuhi bila waktu pemenuhannya telah tiba. Hanya saja, demi terpeliharanya kehormatan dan harga diri manusia,

17 Hotnatalia Naibaho, 'Faktor-Faktor Yang Mempengaruhi Pernikahan Usia Muda (Studi Kasus Di Dusun Ix Seroja Pasar Vii Tembung Kecamatan Percut Sei Tuan Kabupaten Deli Serdang)', Media.Neliti, 2017, 1-12.

18 Maslihatul Aini and Restiana Apriliya, 'Faktor Yang Berhubungan Dengan Pernikahan Dini', Ilmu Keperawatan Dan Kebidanan, 11.2 (2020), 280-90. 
Islam menyerukan agar pemenuhannya dilakukan dengan cara yang benar, yaitu lewat pernikahan. ${ }^{19}$ Adapun tujuan dari pernikahan yang disampaikan oleh Prabandari (2020) ialah menjauhkan dari zinah dan menghindari maksiat, dengan begitu generasi milenial yang melangsungkan pernikan akan mendapatkan pahala dari setiap hal yang dilakukannya karena telah terjalin ikatan yang halal diantara keduanya. Menikah juga berarti mengamalkan ajaran Rasul dan menjalankan Sunnah Rasul sehingga generasi milenial yang menyegerakan pernikahan digolongkan sebagai umatnya Rasululullah. Melalui pernikahan juga akan meregenerasi umat Islam yang unggul, maksudnya generasi milenial yang telah melangsungkan pernikahan akan memperbanyak keturunan umat Islam yang unggul dalam segala aspek kehidupan yang berdasarkan pada Al-Quran dan Hadist. Dengan menikah juga akan mendapatkan kenyamanan dan pembelajaran untuk membina keluarga yang harmonis sesuai dengan tuntunan Islam. ${ }^{20}$

Berdasarkan dalil yang tercantum dalam QS. Al-Isra ayat 32 dan hadits yang diriwayatkan oleh Mutaffaqun Alaih hasil penelitian yang penulis lakukan terdapat beberapa point yang sesuai dan mendukung dalil tersebut seperti beberapa alasan generasi milenial yang berpendapat menyegerakan pernikahan yaitu untuk menghindari maksiat. Namun, generasi milenial yang mendukung teori tersebut hanya sebanyak (30,4\%) atau sama dengan 37 responden, sebanyak $(69,6 \%)$ lainnya atau sama dengan 85 responden menentang teori tersebut karena berpendapat untuk tidak menyegerakan pernikahan karena mementingkan beberapa faktor pendukung lainnya. Padahal dalam dalil yang telah disampaikan jika generasi milenial sudah mampu untuk menyegerakan pernikahan diharapkan untuk tidak menunda pernikahan tersebut agar mampu membatasi diri dari perkara maksiat dan

19 Nashih Nashrullah, 'Pesan Rasulullah Kepada Pasangan Muda Mudi Yang Kasmaran' (republika.co.id, 2020) <https://republika.co.id/berita/qav2on320/pesanrasulullah-saw-untuk-pasangan-muda-mudi-yang-kasmaran>.

${ }^{20}$ Ayu Isti Prabandari, 'Tujuan Pernikahan Dan Manfaat Dalam Islam' (merdeka.com, 2020), p. 5 <https://www.merdeka.com/jateng/5-manfaat-pernikahan-dalam-islammenjaga-diri-hingga-mengamalkan-ajaran-rasul-kln.html?page=5>. 
zinah. Jadi hasil penelitian secara keseluruhan yang telah dilakukan penulis ialah bertentangan dengan dalil yang ada.

\section{Penutup}

Agama memiliki peran yang sangat penting dalam menentukan keputusan pernikahan, sebab agama mengatur segala hal yang terjadi di dalam kehidupan. Oleh karena itu agama memiliki peran yang sangat penting dalam mengambil keputusan terlebih lagi keputusan mengenai pernikahan. Dengan berlandaskan agama pernikahan yang dijalani akan mendapatkan ridho dari Allah Swt dan perjalan dalam kehidupan berumah tangga akan mendapatkan keberkahan. Peran agama dalam menentukan keputusan pernikahan dapat menuntun manusia kepada hal-hal baik dan positif serta dijauhkan dari segala perbuatan jahat dan kerusakan, peran agama juga dapat meningkatkan keimanan dan ketakwaan terhadap Allah swt, serta agama juga berperan untuk menjalin silaturahmi yang baik.

Generasi milenial terbagi menjadi dua kelompok pendapat mengenai pernikahan, yaitu kelompok yang berpendapat untuk menyegerakan pernikahan dan kelompok yang berpendapat untuk tidak menyegerakan pernikahan. Berdasarkan pendapat generasi milenial dalam menentukan keputusan pernikahan, dapat disimpulkan alasan generasi milenial yang berpendapat untuk menyegerakan pernikahan diantaranya karena adanya rasa takut untuk melakukan dosa, maksiat, dan zinah. Selain itu alasan generasi milenial yang berpendapat menyegerakan pernikahan ialah untuk melaksanakan sunnah Rasul dan untuk menaati perintah Allah dalam menyempurnakan imannya. Adapun alasan yang penulis simpulkan dari generasi milenial yang berpendapat untuk tidak menyegerakan pernikahan ialah karena memiliki keinginan untuk membahagiakan diri sendiri dengan cara berkarir yang tinggi, melanjutkan pendidikan ke jenjang yang lebih tinggi, serta keinginan untuk membahagiakan orang tua dengan hasil usahanya sendiri. Faktor yang menjadi alasan generasi milenial untuk 
menentukan keputusan pernikahan diantaranya adalah faktor ekonomi, pendidikan, keluarga, lingkungan, dan faktor kesiapan.

Saran penulis untuk penelitian selanjutnya terkait peran agama dalam menentukan keputusan perkawinan adalah untuk mengkaji perbedaan antara perkawinan yang keputusannya berdasarkan agama dan pernikahan yang keputusannya didasarkan pada cinta atau faktor lain yang tidak berdasarkan agama. Sehingga penelitian selanjutnya dapat menyimpulkan perbedaan antara pernikahan berdasarkan agama dan tidak berdasarkan agama.

\section{DAFTAR PUSTAKA}

Agama, Kementrian, QS. Al-Isra Ayat 32

Aini, Maslihatul, and Restiana Apriliya, 'Faktor Yang Berhubungan Dengan Pernikahan Dini', Ilmu Keperawatan Dan Kebidanan, 11.2, 2020

Andhika, 'Pernikahan Di Era Milenial Dipandang Lebih Rasional' ajaib.co.id, 2020, <https://ajaib.co.id/pernikahan-di-era-milenial-dipandanglebih-rasional/>

Bayali, Cip, 'Menunda Pernikahan Bagi Wanita Karir Menurut Hukum Islam', Hukum Islam, XIII.1, 2013

Fimela, 'Menikah Memang Ibadah' Fimela.com, 2018 <https://www.fimela.com/lifestyle/read/3778550/menikahmemang-ibadah-tapi-bukan-hanya-sebatas-menyegerakan-kata-sah>

Hotnatalia Naibaho, 'Faktor-Faktor Yang Mempengaruhi Pernikahan Usia Muda (Studi Kasus Di Dusun Ix Seroja Pasar Vii Tembung Kecamatan Percut Sei Tuan Kabupaten Deli Serdang)', Media.Neliti, 2017

Isti Prabandari, Ayu, 'Tujuan Pernikahan Dan Manfaat Dalam Islam' (merdeka.com, 2020), p. 5 <https://www.merdeka.com/jateng/5manfaat-pernikahan-dalam-Islam-menjaga-diri-hingga-mengamalkanajaran-rasul-kln.html?page=5> 
Nashrullah, Nashih, 'Pesan Rasulullah Kepada Pasangan Muda Mudi Yang Kasmaran' (republika.co.id, 2020) <https://republika.co.id/berita/qav2on320/pesan-rasulullah-sawuntuk-pasangan-muda-mudi-yang-kasmaran>

Partisipan, 'Jawaban Kuisioner Terbuka'

Rohma Roziki, Mokhamad, 'Konsepsi Pernikahan Dalam Islam Dan Perannya Dalam Menjaga Adab Interaksi Pria-Wanita', Waskita, 2, 2018

Sudrajat, Ajat, 'MENUNDA PERNIKAHAN DALAM ISLAM: Kontruksi Sosial Pelaku Telat Nikah Pada Masyarakat Cisayong Kabupaten Tasikmalaya', $\quad$ Kodifikasia, 8.1 <https://doi.org/10.21154/kodifikasia.v8i1.110>

Unknow, 'Peranan Agama Dalam Pendekatan Kaunseling' (melyloelhabox.blogspot, 2012) <http://melyloelhabox.blogspot.com/2012/12/peranan-agamadalam-perkawinan.html>

Wibisana, Wahyu, 'PERNIKAHAN DALAM ISLAM', Jurnal Pendidikan Agama Islam, 14, 2016

Zulfikar, 'Menunda Pernikahan, Haramkah?', 2019 $<$ https://bincangsyariah.com/kalam/menunda-pernikahanharamkah/> 